\title{
IN VITRO CULTIVATION OF MALIGNANT LYMPHOBLASTS OF TRANSPLANTABLE MOUSE LYMPHOSARCOMA MB (T 86157) WITHOUT TYPICAL MESENCHYME CELLS
}

\author{
BY \\ WILLEMINA M. DE BRUYN*), PH. D. \\ visiting research fellow under George O. Gey, M.D. \\ Division for Cell Physiology \\ The John Hopkins University Medical School
}

\section{INTRODUCTION}

Previous investigations (see Literature) by means of tissue culture methods have shown that the malignant lymphoblasts of mouse lymphosarcoma $\mathrm{MB}$ ( $T$ 86I57) can be cultivated indefinitely when in the presence of actively growing mesenchyme cells. Under the cultural conditions provided, which included the use of low concentrations of embryo extract, a symbiotic relat:onship appeared to be established between the malignant lymphoblasts and the normal mesenchyme. It was also shown that media rich in embryo extract allowed only fibroblasts to proliferate. In the present article we wish to report some results of observations on the cultivation of the malignant lymphoblasts without the supporting mesenchyme.

\section{METHODS AND MATERIALS}

The roller method of Gey (1936) was modified to suit the purpose of this experiment and special coverslips and slides were employed to facilitate the preparation of photographs and motion pictures.

The media were made up of various proportions of balanced salt solution $=$ BSS, beef embryo extract $=\mathrm{BEE}$, human cord serum $=\mathrm{HCdS}$, and Chicken plasma $=\mathrm{ChPl}$ (GEY, 1936, 1945, and 1948; HANKS, 1948). In some experiments approximately 100 Oxford Units of pen:cillin per $\mathrm{ml}$ of culture medium were used.

Bacteriological tests were made in BREWER's Thioglycholate medium. Preparations of smears of cells were stained with WRIGHT's stain.

*) National Cancer Institute (U.S.A.), Postdoctorate Research Fellow, also Leader Division for Tissue Culture, Netherlands Cancer Institute, Amsterdam. 


\section{OUTLINE OF EXPERIMENTS}

On September 24th, 1947, small pieces (approximately I cu mm) of a subcutaneous tumor were set up in roller tubes in three media and at two different temperatures $\left(34^{\circ}\right.$ and $37^{\circ} \mathrm{C}$ ). About eight cultures were placed in each tube. All cultures were embedded in a thin clot of approximately two drops containing ro $\% \mathrm{BSS}$, ro $\% \mathrm{BEE}, 40 \% \mathrm{HCdS}$, and $40 \% \mathrm{ChPl}$. The proportions for the ten drops of the fluid phase were:

\section{I. $75 \% \mathrm{BSS}+25 \% \mathrm{HCdS}$.}

2. Approximately $58 \% \mathrm{BSS}+8 \% \mathrm{BEE}+33 \% \mathrm{HCdS}$.

3. $162 / 3 \% \mathrm{BSS}+\mathrm{I}^{2} / 3 \% \mathrm{BEE}+661 / 3 \% \mathrm{HCdS}$.

These three media will be referred to as Medium I, II and III.

At the beginning of the experiment half of the tubes were treated with one drop of a solution of penicillin containing Iooo Oxford Units per ml. This made a concentration in the medium of approximately 100 Units per $\mathrm{ml}$. Later, when it was shown that this amount of penicillin did not effect the cultures adversely, this antibiotic was used in some cases only as a precaution against contamination (7). Until November Ioth, 1948, 47 days after explantation, all cultures were treated three times a week. The usual procedure was to renew the fluid and alternate with a renewal of fluid and patching with clot. Transfers were made when necessary. From that date on the cultures incubated at $34^{\circ} \mathrm{C}$ were treated twice a week and beginning July Ist, I948, 280 days after explanation, once a week. The $37^{\circ} \mathrm{C}$ cultures were treated twice a week beginning January 26th, 1948, or 124 days after explantation.

Until February 2d, 1948, or I3 I days after explantation, some cultures were treated with non-frozen serum. As no differences in growth were observed between the cultures treated with frozen $\left(-40^{\circ} \mathrm{C}\right)$ and those with non-frozen serum, only frozen serum was used thereafter. From February 2d, 1948, or I3I days after explanation, special treatment was given to the cultures derived from tubes numbered $I_{3}$ and $I_{4}$, and will be described in detail later.

The following is a list of the original tubes set up

I. Medium I with frozen serum and incubated at $37^{\circ} \mathrm{C}$ (One week later in Medium II).

2. Same +100 Units per $\mathrm{ml}$ penicillin.

3. Medium I with non-frozen serum and incubated at $37^{\circ} \mathrm{C}$. (One week later in Medium II).

4. Same + Ioo Units penicillin per $\mathrm{ml}$.

5. Medium I with frozen serum, incubated at $34^{\circ} \mathrm{C}$.

6. Same +100 Units penicillin per $\mathrm{ml}$.

7. Medium I with non-frozen serum, incubated at $34^{\circ} \mathrm{C}$.

8. Same +100 Units penicillin per $\mathrm{ml}$.

9. Medium III with frozen serum and incubated at $37^{\circ} \mathrm{C}$. 


\section{RESULTS}

TUBes I-4. In these tubes the fibroblasts outgrew the lymphoblasts. In tubes 3 and 4 for instance no lymphoblasts were observed after a few transfers. In tube 4 , after 321 days of cultivation (IO-VIII-I948), actively growing mesenchyme cells were the only cells to be seen. Inoculations gave no tumors.

TUBes 5 and 6 . In these tubes fibroblasts and lymphoblasts grew beautifully. Later tube 6 was lost accidentally. The cultures in tube 5 grew slowly. at $34^{\circ} \mathrm{C}$. The clot did not liquefy and no cell desintegration took place. Therefore it was not necessary to transfer often, and the cultures were allowed to become larger, than would have been possible at $37^{\circ} \mathrm{C}$ as had been shown by preliminary experiments. The first transfer of tube 5 was made after 40 days of cultivation. From that date on several more transfers of this tube were made including daughter tubes. Many of these tubes were discarded after a few months, when it was seen that cellular activity and cell population were decreasing. This may have been caused by keeping the cultures too long in the same tube. To date, $3^{2 I}$ days after explantation (Io-VIII-I948), five tubes are left ( $5 \mathrm{ab}, 5 \mathrm{ac}, 5 \mathrm{ac}, 5 \mathrm{~b} 2$ and $5 \mathrm{~b} 2 \mathrm{r}$ ). In these tubes, in addition to the round cells, fibroblasts have continued to live but they are less numerous than they were during the first period of cultivation. On June Ist, I948, from tube 5 the liquid phase which contained free cells was injected into a mouse. A tumor was produced which killed the mouse on the I6th day. The $1 \mathrm{ym}$ phoblasts therefore retained their malignant characteristics after an eight months period of cultivation.

TUBES 7 and 8. In these tubes there was good growth of both fibroblast and lymphoblasts for about six months. Several transfers and daughter tubes had by then been established. Later growth decreased and this series was discanded. It is possible that the colonies were allowed to become too old and that too extensive subcultivation was attempted.

Tube 9. Of particular interest were the results in tube 9. This tube was set up in the ordinary sfock medium $=$ Medium III. Figure I shows the history of this tube. There was an abundant growth of fibroblasts, with many lymphoblasts and a few macrophages. This abundant growth made it necessary to transfer rapidly and often. It was possible to divide each culture into two daughter tubes at three of the first four transfers. Until November I4th, $5^{2}$ days after explantation, subcultures were made six times. During this period of cultivation the fibroblasts became swollen and granular and after the sixth subculture they became less numerous in all tubes. The fluid was clear and there was no apparent infection. As the most important results were obtained with tube $\mathrm{I} 3$, the history of this tube will be related further. This tube was set up October I7th, 1948, 23 days after explantation, from tube II and at $37^{\circ} \mathrm{C}$. By November I2th, 49 days after explantation, there were slightly granular and more or less swollen mesenchyme cells and also active lymphoblasts pres- 
ent. A sixth transfer was made. Only a few fibroblasts migrated out of the explant, but surprisingly large numbers of round cells appeared. On November 24th, 6I days after explantation, round cells were growing luxuriantly throughout the medium and many of them seemed larger than before. They were also more granular and more vacuolated than before. Only a few typical fibroblasts could be observed. On January 2d, I948, Ioo days after explan-

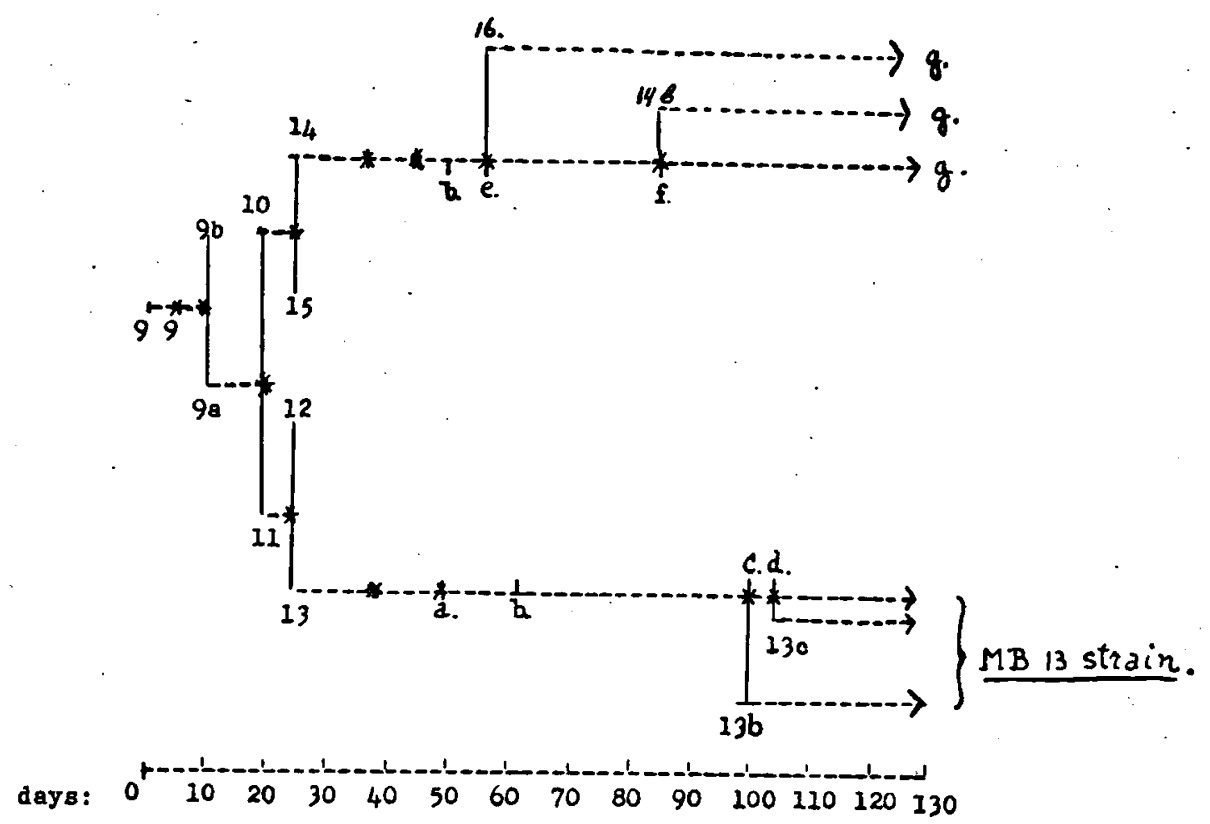

Fig. I. History of tubes 9, I3, and I4.

* transfer.

a fibroblasts swollen and granular. 6th transfer made.

b lymphoblasts all throughout the medium, many swollen and granular.

c lymphoblasts in different sizes, fluid transferred to tube $\mathrm{I} 3 \mathrm{~b}$.

d fluid transferred to tube $\mathbf{I} 3 \mathrm{c}$.

e fluid transferred to tube 16 .

f fluid transferred to tube $14 \mathrm{~b}$.

g discarded after 196 days of cultivation.

tation, many round cells of different sizes were observed. Only a few macrophages and fibroblasts were seen.

The liquid phase contained many cells and therefore another method of. transfer was used. The liquid phase containing free floating cells was put in a new tube already prepared with a blank clot (tube $\mathbf{I} 3$ b). A similar transfer was made three days later (tube $\mathrm{I}^{3} \mathrm{c}$ ). Such transfers were made at periodic intervals, first into tubes with blank clots, later into tubes without clots. Various combinations from the quantities of cell suspensions and media were used. Transfers from subcultures of tube $\mathbf{I} 3$ have been made several times. 
Tube ${ }^{3} 3$ has been maintained until the present time, August Ioth, I948, a total of 298 days. The clot is now dark brown with precipitate and debris, and most of the cells have a granular appearance. Since January 2d, 1948, Ioo days after explantation, the tube has been treatel twice a week instead of three times.

On February 2d, 1948, I3 I days after explantation, this technique was again changed. It was thought that complete renewal of the fluid of these cells might be unfavorable. Therefore, it was decided to remove only half of the fluid medium and to replace it with an equal amount of fresh fluid. This change was applied both in routine treatment and in transferring the cultures from tube to tube.

It is apparent, that from tube 13 there has originated a strain of cells (designated as strain M B I3), which has been successfully cultivated in the fluid phase of Medium III, without the presence of typical mesenchyme cells, without clot, and with these cells growing only on $\mathrm{g}$ la s s. At the present time there are under cultivation several tubes of this strain at $37^{\circ}$ and $34^{\circ} \mathrm{C}$. The morphology of the cells differs from tube to tube and may even change from one time to another in the same tube during the period of cultivation. Also at times the cells become granular and they appear crenated. They do not disintegrate however, but continue to increase in number for long periods of time. Phase photographs (Fig. 2) show variation in size and blunt processes, occasionally with a hook and cells with "tail". Few to numerous vacuoles are shown. Cells show prominent nucleoli.

Fluid from tubes containing this cell strain were submitted from time to time to bacteriological tests, all of which were negative. At different intervals the liquid phase, containing cells was used for injections into susceptible mice to check whether the cells would produce a tumor. Simultaneously, smears were made to ascertain the morphology of the cells. Twenty four mice were injected. Only four mice have developed tumors up to August Ioth, 1948. The history of these mice is related herein :

Fifty four days after the change in the cells was noted (5-I-1948), two mice were injected with fluid from tube $\mathbf{I} 3 \mathrm{~b}$; one intraperitoneally and the other subcutaneously. Both developed tumors within 18 days.

Ninety four days after this inoculation (8-IV-1948), two mice were injected with fluid from tube $\mathrm{I} 3 \mathrm{~h}$, one intraperitoneally and the other subcutaneously. Only the former mouse developed a tumor and died on the 18 th day after inoculation.

Nine days later, (17-IV-I948), one mouse was injected subcutaneously with fluid obtained from tube $13 \mathrm{~h}$ ". This mouse developed a tumor and was sacrificed two months after inoculation (18-VI-I948).

Mice injected after April I7th, 1948, have developed no tumors.

The in vivo characteristics of the original tumor $\mathrm{MB}$ have not changed during the course of this experiment. The tumor must be transplanted every seven or eight days, since death occurs on the 8th or 9th day. Cell suspensions from tube $5 \mathrm{ac}$, containing lymphoblasts and typical mesenchyme have proBijdragen tot de Dierkunde, Afl. 28. 
duced tumors with death occurring on the I6th day. One may therefore assume that the malignancy of the lymphoblasts of strain 3 grown without typical mesenchymecells has been reduced.

The following types of cells were seen on stained smears taken from different cultures during cultivation:

I. Lymphoblasts or MB cells as described previously (see Literature; Fig. 3) when in the presence of mesenchyme cells. Some have but scanty cytoplasm, others have more. The cytoplasm is basophilic and usually contains from one to 5 or 6 vacuoles. The nucleus is large and contains 2,3 or 4 nucleoli.

2. Larger cells with more cytoplasm, less basophilic and of ten vacuolated: The nucleus is often excentric. Sometimes the cells are binucleate.

3. Very large cells, with pale occasionally vacuolated cytoplasm and a small, often excentric nucleus, about the same size as from the above types of cells.

4. Very small cells like small lymphocytes.

These four cell types have been seen on all smears, but their relative numbers vary.

5. In smears from the original tube 13 and tube 5 ac in which typical fibroblasts were present, a few cells with sausage-shaped nuclei were seen.

\section{DISCUSSION}

A change in the cells being studied in this experiment has been observed to take place in tubes I3 and I4, which were set up in Medium III with clot. In these tubes the mesenchyme cells grew very rapidly at first, then became granular and swollen, and later seemed to disappear. This is not unlike the results obtained when normal new born mouse mesenchyme cells were cultivated under similar cultural conditions, several times, and in each case the cells petered out. The lymphoblasts on the other hand in this medium increased in numbers and they no longer needed the typical mesenchyme for their growth. In former experiments (see Literature), it has been reported that the MB cells grew best when in the presence of a well established mesenchyme stroma. The supporting mesenchyme could be derived either from the tumor stroma ${ }^{1}$ ), or from normal mouse embryo fibroblast cultures 2 ). Since it has not been possible to cultivate suspensions of $\mathrm{MB}$ cells taken from fresh tumor in the

I) Such an MB strain was grown for $2^{1 / 2}$ years at the laboratory of Dr. GEoRGE O. Gey, by Mrs Margeret Gey, and was lost accidentally.

2) Such an MB strain was grown for eight months by the author and produced a tumor when injected. This strain had to be discarded due to the loss of laboratory facilities at the beginning of the war. 


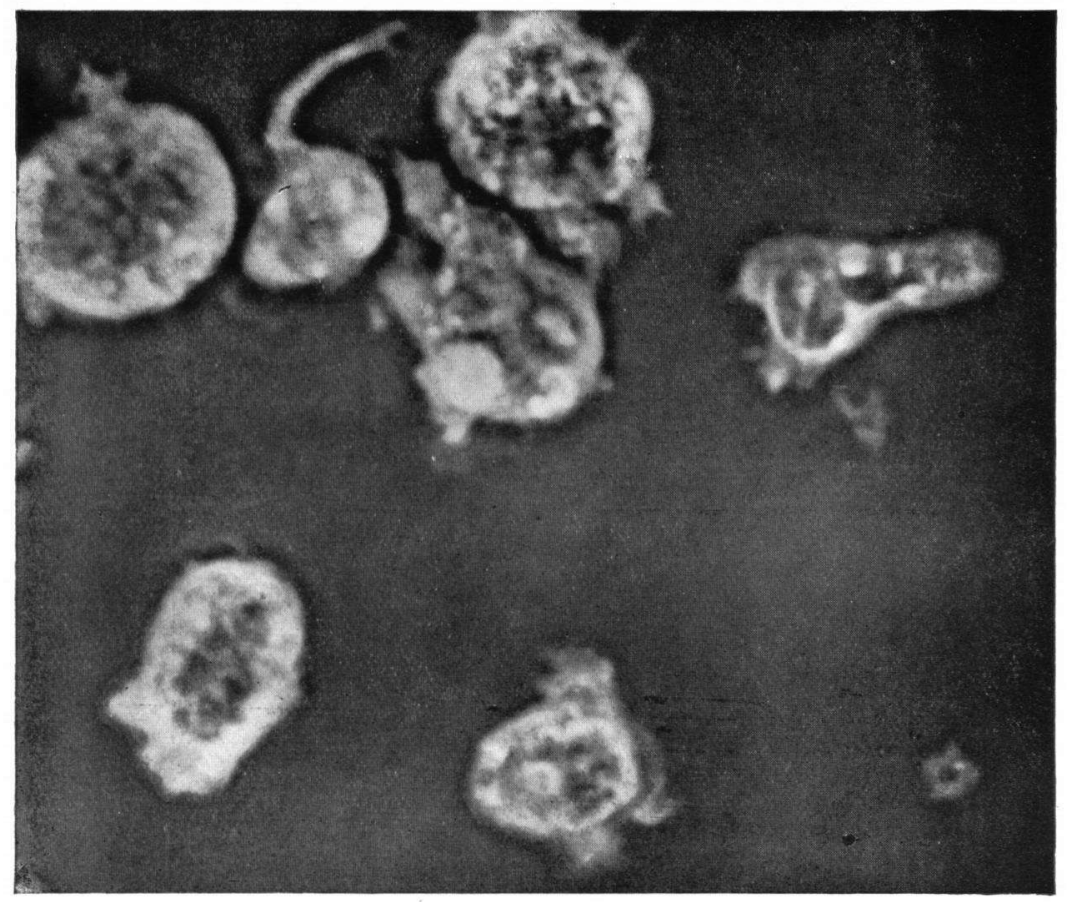

Fig. 2. Living lymphoblast "MB-I3" cells. Photo bright contrast phase. Magn. $\times$ rooo. Variation in size and blunt processes occasionally with a hook and cells with "tail". Few to numerous vacuoles are shown. Cells show prominent nucleoli. 


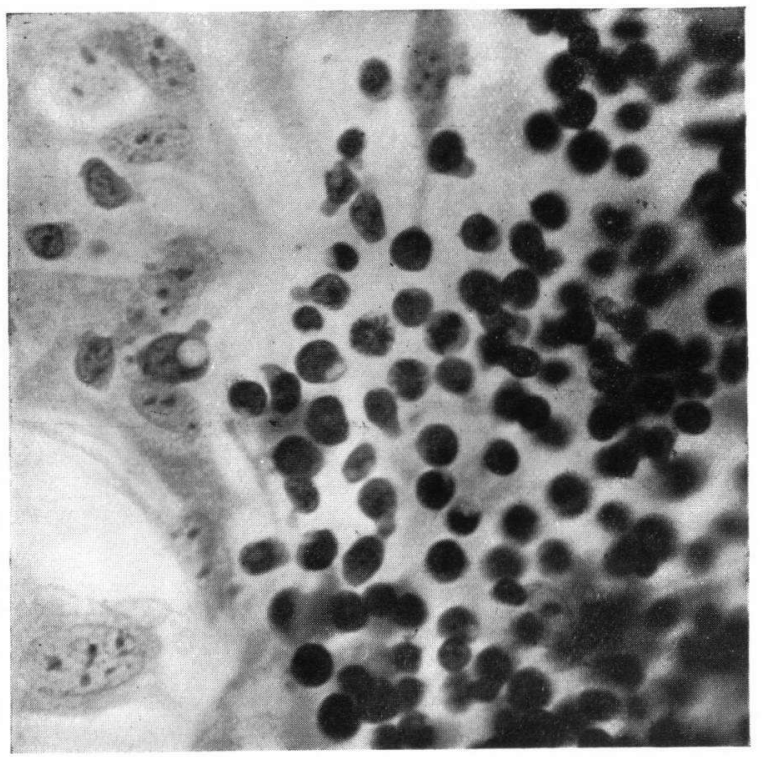

Fig. 3. Fixed and stained culture of lymphosarcoma MB. Large mesenchyme cells and many lymphoblasts. Blunt "tails", large vacuoles, and mitosis are shown. Magn. $\times 500$. 
Medium III without an already established mesenchyme, it is evident that the lymphoblasts in tubes 13 and 14 , which lacked the typical mesenchyme, must have been altered in some way to enable them to grow independently. We do not know what these changes are. We do know that they are not related to the presence of bacteria since no organisms were found when bacterial examinations were made. It is quite probable these apparently altered cells arose as a result of gradual adaptation to a medium which became unfavorable for fibroblasts and contained a fair proportion of their own metabolites.

Accompanying these changes in cell behavior there appeared a decreased ability to produce a malignant tumor. The cause of this phenomenon is as yet unknown. It may be that the cells have lost the ability to grow in the mouse after having been grown for a long period of time in an entirely heterologous substrate. Other investigators reported similar results (EARLE, personal communication). The lymphoblasts in tube $5 \mathrm{ac}$, which were grown during this same period with mouse mesenchyme cells (derived from the tumor stroma), produced a tumor within the usual time. They did not lose their ability to grow in the mouse. Experiments are now underway to find out if the transplantability will be restored when again grown with typical mouse mesenchyme.

The following explanations are offered as to why the cells grew better when only half of the fluid is replaced by fresh medium, than when all fresh medium is used.

First: These cells probably grew better when confronted with a fluid environment containing nutrients and metabolites in quantities roughly approximating those needed during optimal growth and in which the cells enjoy some equilibrium. It is obvious that there must exist a considerable difference between the fresh medium and the medium in which the cells have been grown under fairly optimal conditions for a short period of time. This one may call the "lived in" medium or the "cell adapted" medium. The washing of tissue with balanced salt solution or Tyrode's solution before transferring or patching has been found unfavorable. In transferring a piece from a compact tissue culture some of the "lived in" fluid is probably retained between the cells and may be present after the cultures have been set up in fresh medium. The lymphoblasts however do not adhere to each other as do the cells of other tissues. Therefore, no intercellular fluids are present to assist in the establishment of a new culture when it is placed in an entirely fresh medium. By replacing only a part of the fluid, enough substrate to which the cells have been adjusted is present to allow continued growth. In attempts to obtain cultures from one cell this may be an important factor.

Second!y: One must realize that in removing any fluid one decreases the cell population, since there are always many free cells in the liquid phase. When all the fluid is taken out, this decrease in cell population may be so great that it may be quite difficult for the few remaining cells to establish a favorable environment for themselves. This reduction in cell population with each treat- 
ment accounts partially for the very long time that some of the cells may be kept in the same tube, in good condition. Such cells have been maintained in tube 13 for ten months and in several other tubes for four or five months.

It is not yet possible to give an explanation for the wide variation in cell size which is found. One is inclined to believe that the small, the medium-sized and the somewhat larger cells are closely related, and that these types represent transitional stages in the development of the lymphoblast MB cell. We do not know how to classify the very large cells.

To obtain more information about the relationship between the different cell types, attempts will be made to follow their fate for a longer period of time. Micromanipulater experiments will be carried out. One-cell cultures of each type of cell will be made and these will be studied.

If we can succeed in establishing and maintaining a pure cell strain from one or from each type of cell, such a strain or strains will provide an ideal tool for the investigation of cellular phenomena on all levels of organisation.

\section{ACKNOWLEDGEMENT}

The author wishes to express her great thankfulness for the advice, help and hospitality given to her by Dr. George O. Gey and Mrs Margeret Gey. She also wants to thank the staff of the Division for Cellular Physiology for their coöperation. The help of Mr. William B. Freedman in preparing stained smears is appreciated.

\section{SUMMARY AND CONCLUSIONS}

I. In attempts to cultivate the malignant lymphoblasts of transplantable mouse lymphosarcoma MB ( $T$ 86I75) without a supporting mesenchyme stroma, a strain of cells (MB I3) was established which contains no typical fibroblasts.

2. Cultures were set up in three different media. Some were cultivated at $37^{\circ} \mathrm{C}$ and some at $34^{\circ} \mathrm{C}$.

3. After eleven months of cultivation some tubes maintained at $34^{\circ} \mathrm{C}$ in a clotted substrate and supernatant fluid still showed lymphoblasts and fibroblasts. Fluid, containing free cells, from one of these cultures produced a tumor after 18 days.

4. Other cultures maintained at $37^{\circ} \mathrm{C}$, in a different medium showed only fibroblasts after prolonged cultivation.

5. In previous published reports it was concluded that the malignant lymphoblasts strain $\mathrm{MB}$ required an established mesenchyme for continued maintenance in vitro. But in these experiments some cultures originally set up with clotted substrate and supernatant fluid after 50 days of maintenance showed a disappearance of fibroblasts and good proliferation of the malignant lymphoblasts, which differred markedly in size, and with some large round cells, which have not been identified. It seemed apparent that the lymphoblasts had changed. It is now possible to maintain these cells as a fluid culture without clot and without a typical mesenchyme present.

6. Early inoculations showed that these cells could produce a tumor. After growing independently for 157 days they seem to have lost their ability to produce a tumor in originally susceptible mice.

7. Partial replenishment of fluid medium with renewal of only part of the used medium appears to be the best method of maintaining growth of these free cells in fluid medium. 


\section{LITERATURE}

BRUYN, W. M. DE, 1938. A comparative study of two transplantable round-cell sarcomas of mice by the tissue culture method. Acta Neerlandica Morphologiae, Vol. I, $\mathbf{n}^{\circ} 4$, pp. $358-374$.

- I943. Onderzoek van rondcelsarcomen van de muis in vivo en in vitro. Handelingen van het 29ste Nederlandsch Natuur- en Geneeskundig Congres, pp. 34-36.

R. Korteweg and E. Kits van Waveren, to be published.

Gey, G. O. and M. K. GEY, 1936. The maintenance of human normal cells and tumor cells in continuous culture. Am. J. Cancer 27, pp. 45-76.

- John H. Hanks and Rachel Barrett, I948. Retardation of Growth and Metabolism of Normal and Malignant Cells during continuous cultivation. Growth $12, \mathrm{n}^{\circ} \mathrm{I}$, pp. 69-105.

-, M. K. Gey, F. InUI and H. Vedder, 1945. The effects of crude and purified penicillin on continuous cultures of normal and malignant cells. Bulletin of the John Hopkins Hospital 77, no. 2, pp. 116-131.

Hanks, JoHN H., I948. The longivity of chick tissue cultures without renewal of medium. J. Cell. and Comp. Physiol., v. 3I, $\mathrm{n}^{\circ}$ 2, pp. 235-260. 